\title{
INFLUENCES OF TRADITIONAL MULCHES ON FLOWER PRODUCTION AND PETAL COLORATION OF DIANTHUS (Dianthus Chinensis Lin.)
}

\author{
M. H. Kabir, A. H. M. Solaiman, N. Das and A. F. M. J. Uddin \\ Department of Horticulture and Postharvest Technology \\ Sher-e-Bangla Agricultural University, Dhaka, Bangladesh
}

\begin{abstract}
An experiment was conducted to understand the effect of traditional mulches on plant growth, flower induction, petal coloration and yield of Dianthus chinensis at Horticultural Farm, Sher-e-Bangla Agricultural University, Dhaka. Four mulch treatments C, control; SM, straw mulch; WHM, water hyacinth mulch; BPM, black plastic mulch were examined under this study. Black plastic mulch showed better performance than other treatments. Highest plant and flower growth, early flowering and maximum number of flowers were observed from black plastic mulch treatment followed by water hyacinth mulch and straw mulch respectively whereas the lowest was observed from control. Deep colored flower was produced from black plastic mulch treated plants and light colored flower from control.
\end{abstract}

Key Words : Coloration, Dianthus chinensis, Flower production, Mulch

\section{INTRODUCTION}

Dianthus (Dianthus chinensis), is an important flower crop all over the world, belonging to the family Caryophyllaceae, native to Eastern Asia (Singh, 1985). Genus Dianthus comprises of about 300 species of flowering plants. The species is an annual, free blooming plant which is pink, white, rose, scarlet, crimson, violet, maroon, mauve and purple in color. The plant is mostly suitable for beds, boarders, rock gardens and pots (Singh, 1985). The market of herbaceous flowers has expanded rapidly. Demand of inexpensive attractive flowers is increasing day by day. Its habit is large quantity flowering and wide spectrum of attractive colors attracts the attention of flower growers. In Bangladesh, it is one of the most rarely grown flowers and its use is not yet wide spread due to non-familiarity to the people though it has a big economic demand.

Different cultural practices can play important role in manipulation of flowering date, plant height, branching etc (Relf and McDaniel, 2001). Different management practices have to be done to obtain more desired flowers in a suitable time with minimum cost. Moisture management is one of the most important management practices to produce quality flowers of Dianthus; even small improvement in quality can generate significant economic and aesthetic returns. Dianthus is grown during winter season where rainfall is less or scanty. But water in needed for growth, development and flowering of plant. Additional irrigation may cause increased cost of production. Mulching may be used to minimize the cost of production. 
Mulches reduce the rate of water loss from the soil. It prevents water from moving in to the air. It stimulates microbial activity in soil through increasing soil temperature, which improves agro-physical properties of soil. Waggoner et al. (1960) reported that various types of mulching materials affected thermal balance in the soil. Mulches may also influence in petal coloration and flowering time manipulation as well as quality of flower (Granberry, et al., 1994). However, experimental report on mulching for the flower production of dianthus is lacking. Considering the facts, this study was undertaken to know the affect of traditional mulches on growth, flower production and quality of dianthus.

\section{MATERIALS AND METHODS}

This field research was conducted at Horticultural Farm, Sher-e-Bangla Agricultural University, Dhaka during the period from October 2005 to February 2006. Soil of the experimental plot was clay type belonging to Modhupur Tract region (UNDP, 1988). Dianthus cultivar's 'Heritage Rose Eye' was used in the research work and seeds were collected from a renowned seed store, Dhaka, Bangladesh. There were four (4) treatments viz. C, control (no mulch); SM, straw mulch; WHM, water hyacinth mulch and BPM, black plastic mulch. Experiment was laid out in a Randomized Complete Block Design with three (3) replications. Plant spacing was $30 \times 20 \mathrm{~cm}$ and each plot size was $1.2 \mathrm{~m} \times$ $1.2 \mathrm{~m}$. Seedlings were produced in the seedbed and seedlings of 25 days old were transplanted in the main field at 30 November 2005. $\mathrm{pH}$ of the experimental soil was 5.8 to 6.8. Average day and night temperature were $18^{\circ} \mathrm{C}$ and $10^{\circ} \mathrm{C}$ respectively. Land was opened on 15 days before transplanting. Recommended doses of manures and fertilizers (Cowdung $10 \mathrm{~kg} / \mathrm{m}^{2}$, TSP $20 \mathrm{~g} / \mathrm{m}^{2}$, MP $20 \mathrm{~g} / \mathrm{m}^{2}$ ) were applied in the experimental plots and mixed with plot soil. Cowdung was applied during land preparation. All of the TSP and MP were applied during transplanting. Seedlings were transplanted in the afternoon and were protected from sun providing leaf sheath of banana.

Mulches of water hyacinth $(7 \mathrm{~cm})$ and rice straw $(7 \mathrm{~cm})$ were applied immediately after transplanting while polythene sheet was spreaded over the plot immediately before transplanting of seedling. Gap filling, weeding, and pesticide application were done when necessary. Data on plant height, number of leaf per plant, days to first bud formation, bud diameter, bud growth at every alternate day, color measurement of full bloom petals were collected.

Petal color at three different locations of the top center of outer epidermis was measured using a handy-type tristimulus colorimeter, NR-3000 (NIPPON Denshoku), followed by $L^{*}$ (lightness), $a^{*}$, and $b^{*}$ (two Cartesian co-ordinates), based on the CIELab scale with the standard CIE observer ( $10^{\circ}$ visual field) and the CIE standard illuminant $D_{65}$ (CIE, 1986 and McGuire, 1992). Beams whose effective axes were at the angle of $45 \pm 2^{\circ}$ from the normal to the specimen surface in illuminated petal. Metric chroma, $C^{*}$ and hue angle, $h_{a b}$, were calculated according to the following equations: $C^{*}=\left(a^{* 2}+b^{* 2}\right)^{0.5}$ and $a b=\operatorname{tang}^{-1}\left(b^{*} / a^{*}\right)$ (Uddin et al., 2002; Uddin and Kabir, 2006). 
Collected data were statistically analyzed using MSTATC computer package program. Means for all the treatments were calculated and analysis of variance for all the characters was performed by F- variance test. Significant differences among the pairs of treatment means were evaluated by Least Significance Difference Test (LSD) (Gomez and Gomez, 1984).

\section{RESULTS AND DISCUSSION}

\section{Plant height}

Plant height was recorded at different growth stages with 10 days interval. Plant height varied significantly due to different types of mulch practices and it was highest in black plastic mulch (BPM) treatment followed by water hyacinth mulch (WHM). Plant height was increased with time and was highest $(47 \mathrm{~cm})$ at 50 DAT, which was recorded from black plastic mulch (BPM) and was lowest from control or no mulch treatment (Fig. 1).

\section{Number of leaf per plant}

Significant variation was found in case of production of number of leaves per plant due to mulch treatments. Number of leaf was maximum (220) at 60 DAT in black plastic mulch (BPM), which was closely followed by water hyacinth mulch (WHM) whereas the minimum no. of leaf (150) was recorded from control treatment (Fig. 2). Increased no. of leaf may indicated healthy growth and development of plant. There was a rapid increase of number of leaf from 30 DAT to 40 DAT in all treatments.

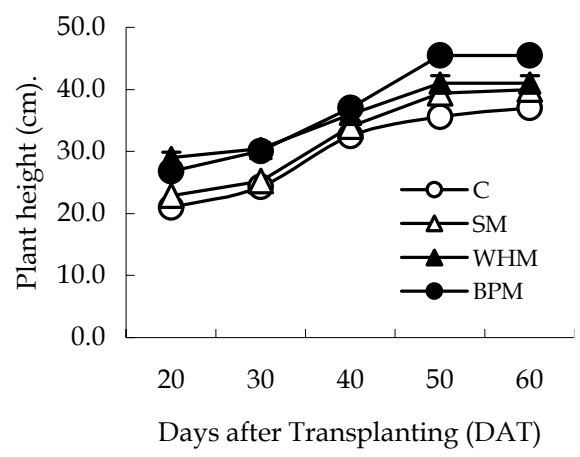

Fig. 1. Variation in plant height with days after transplanting of dianthus due to different mulches. C, Control; SM, Straw mulch; WHM, Water hyacinth mulch; and BPM, Black plastic mulch

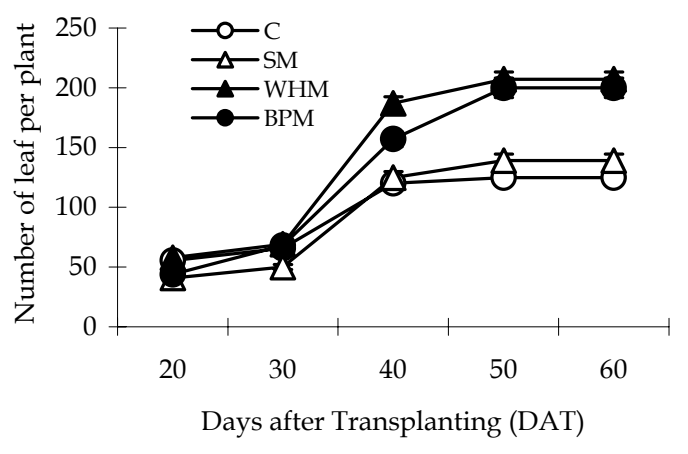

Fig. 2. Variation in leaf number with days after transplanting of dianthus due to different mulches. C, Control; SM, Straw mulch; WHM, Water hyacinth mulch; and BPM, Black plastic mulch

\section{Flower bud initiation and development}

Significant variation was observed with days required for first bud formation. Twentyfour days after transplanting (DAT) were needed in black plastic mulch (BPM) treatment 
whereas 32 days were recorded in control (Fig. 3). It was also observed that flower bud diameter was increased gradually in all treatments and the diameter was maximum (10 $\mathrm{cm})$ in black plastic mulch (BPM), which was minimum $(8 \mathrm{~cm})$ in control treatment for 40 DAT, but in other dates, straw mulch produced minimum diameter (Fig. 3). Results indicated that black plastic mulch produced large sized flowers than other treatments, which was followed by water hyacinth mulch (WHM).

\section{Total number of flowers per plant}

Total number of flower was also found to differ significantly with mulching treatments (Fig. 4). Plants grown by using black plastic mulch (BPM) gave maximum number of flowers (178) at 60 DAT, which was followed by water hyacinth (WHM) and rice straw mulch (SM) treatments respectively. Control treatment showed the minimum number of flowers (100). Result showed that the black plastic mulch produced near two time's higher number of flower than that from control.
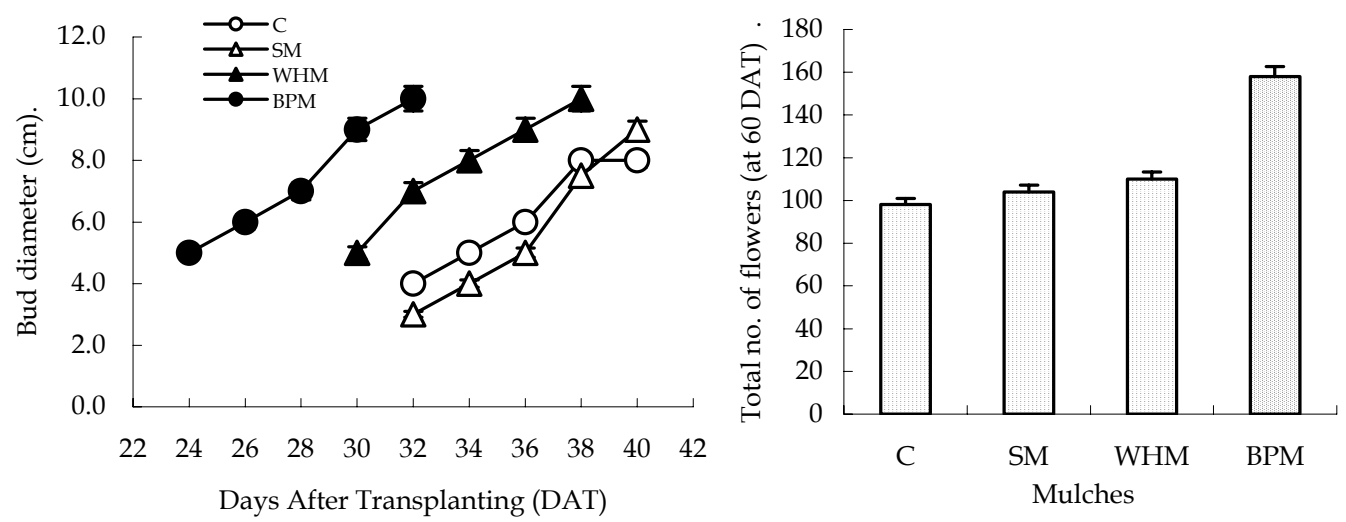

Fig. 3. Variation in flower bud initiation and development of dianthus due to different mulches. C, Control; SM, Straw mulch; WHM, Water hyacinth mulch; and BPM, Black plastic mulch

Fig. 4. Variation in flower production of dianthus due to different mulches. $\mathrm{C}$, Control; SM, Straw mulch; WHM, Water hyacinth mulch; and BPM, Black plastic mulch

\section{Petal coloration}

Different mulching practices showed significant influence in petal coloration of dianthus. Deepest colored $\left(\mathrm{L}^{*} 48\right)$ flowers were recorded from the plants produced from black plastic mulch (BPM) and lightest colored $\left(\mathrm{L}^{*} 61\right)$ flowers were found in control (Table 1). Color was identical in the flowers mulched with water hyacinth (WHM) and straw mulch (SM). Considering chroma, it was observed that black plastic mulched flowers significantly produced the highest chroma (85.6) (Table 1). There was no chroma variation observed in between straw mulch (SM) and water hyacinth mulch (WHM) treated plants. In case of hue, highest angle $\left(337.4^{\circ}\right)$ was recorded from flowers treated with straw mulch $(\mathrm{SM})$, which was identical with flowers from water hyacinth mulch 
(WHM) (337\%). Lowest hue angle $\left(328.4^{\circ}\right)$ was seen in control (Table 1$)$. Results observed in black plastic mulch and control treated flowers was identical.

Table 1. Influence of traditional mulches on the petal coloration of Dianthus

\begin{tabular}{c|c|c|c}
\hline \multirow{2}{*}{ Treatments } & \multicolumn{3}{c}{ Colorationy } \\
\cline { 2 - 4 } & $\mathrm{L}^{*}$ & $\mathrm{C}^{*}$ & $\mathrm{~h}^{\circ}$ \\
\hline C & $61.0 \mathrm{a}$ & $36.35 \mathrm{~d}$ & $328.4 \mathrm{a}$ \\
SM & $56.0 \mathrm{~b}$ & $57.38 \mathrm{c}$ & $337.4 \mathrm{~b}$ \\
WHM & $55.0 \mathrm{~b}$ & $64.07 \mathrm{~b}$ & $337.0 \mathrm{~b}$ \\
BPM & $48.0 \mathrm{c}$ & $85.58 \mathrm{a}$ & $329.8 \mathrm{a}$ \\
\hline
\end{tabular}

x C, control; SM, Straw Mulch; WHM, Water hyacinth Mulch; and PM, Polythene Mulch; y $\mathrm{L}^{*}$, lightness; $C^{*}$ (Chroma); $\left(a^{*} 2+b^{*} 2\right) 1 / 2$, and $h^{\circ}$ (hue angle); $b^{*} / a^{*} ;\left(a^{*}\right.$, a hue of green to red; $b^{*}$, blue to yellow); Means having common letters are not statistically different at $5 \%$ level by LSD

Results showed that mulch treatments had significant effect on flower production and petal coloration of dianthus. Considering almost all parameters studied, black plastic mulch (BPM) showed better performance than other treatments.

Mulches serve as physical barriers that dissipate erosive energy from raindrops, thereby protecting the structure of the soil at the surface and thus improving permeability of the soil and reducing soil erosion. Black plastic mulches may also serve as vapor barriers, thus reducing evaporation of soil moisture. As a result more uniform moisture was maintained under the plastic mulch and fertilizer beneath the mulch is not lost to leaching. So, fertilizers are efficiently used and not wasted (Relf and McDaniel. 2001). Soil under the plastic mulch remains loose, friable and well aerated. This provides for excellent root growth.

Black plastic mulch reduces light penetration to the soil. So that weeds generally cannot survive under the mulch, results less weed plant nutritional competitions. Side by side it warms the soil by contact. The greatest benefit from plastic mulch is raising the soil temperature in the planting bed to allow early seedling emergence and quick vegetative growth (Granberry et al., 1994). Black plastic mulch showed an earlier harvest on an average 9-14 days of dianthus flower.

This indicated that black plastic mulch was effective for better moisture management, increased temperature and enhanced early flowering, which was followed by water hyacinth mulch. Increased number of flowers per plant under mulch treatment may be attributed to the availability of more moisture; proper nutrient availability etc. ultimately produced more vivid colored flowers than control.

In conclusion, plastic mulches modified soil temperature where plants were grown. Soil temperatures modified by the black plastic mulches directly influenced observed differences in plant growth and total flower yield among various mulch treatments. 


\section{REFERENCES}

CIE, 1986. Recommendations on uniform color spaces, color difference evaluations and psychometric color terms. CIE Central Bureau, Colorimetry, 2nd ed. Commission, Internationale de l'Éclairage, Central Bureau, Vienna, Austria. pp. 1-83.

Gomez, K. H. and Gomez A. A. 1984. Statistical Procedure for Agricultural Research. Second Edn, Wiley Inter Science Publication, John Wiley and Sons, New York. p. 680.

Granberry, D. M., Kelley, W. T., Chance, W. O., McLaurin, W., Harrison, K. A. and Sanders, D. 1994. Benefits of plasticulture for commercial vegetable production. University of Georgia, Fort Valley State College, Cooperative Extension Service, Bulletin, p. 1108.

McGuire, R. G. 1992. Reporting of objective color measurements. Hort. Sci., 27. pp. 1254-1255.

Relf, D. and McDaniel, A. 2001. Mulches for the Home Vegetable Garden. Virginia Tech. Dept. Horticulture, pp. 426-326.

Singh, S. P. 1985. Short Season Flowering Plants. B. R. Publishing Corporation, Delhi. p. 96.

UNDP. 1988. Land Resource Appraisal of Bangladesh for Agricultural Development Report 2: Agro-ecological Regions of Bangladesh, FAO, Rome, Italy. p. 577.

Uddin, A. F. M. J. and Kabir, M. H. 2006. Application of Homeopathy medicine on flower production of Phlox paniculata Linn. International J. Sustain. Agril. Tech., 2(7) : 16-20.

Uddin, A. F. M. J., Hashimoto, F., Nishimoto, S., Shimizu, K. and Sakata, Y. 2002. Flower growth, coloration and petal pigmentation in four lisianthus cultivars. J. Jpn. Soc. Hortic. Sci., 71, pp. 40-47.

Waggoner, P. E., P. M. Miller and Deroo, H. C. 1960. Plastic mulching principles and benefits. Bull. No. 634. Agric. Expt. Stat., New Haven. 